\title{
Desquamative gingivitis: a definite indicator for mucocutaneous disorders
}

\author{
Melwin Mathew (D) , Vijayendranath Sujir Nayak, ${ }^{2}$ Santhosh Kumar Ramaiah, ${ }^{3}$ \\ Shruthi Sethuraman ${ }^{4}$
}

'Periodontics and Oral Implantology, Manipal University College Malaysia, Bukit Baru, Melaka, Malaysia ${ }^{2}$ Oral Medicine and Oral Radiology, Manipal University College Malaysia, Bukit Baru, Melaka, Malaysia

${ }^{3}$ Periodontics and Oral Implantology, Sri Siddhartha Dental College, Tumkur, Karnataka, India

${ }^{4}$ Periodontics and Oral Implantology, Vydehi Institute of Dental Sciences, Bangalore, Karnataka, India

Correspondence to Dr Melwin Mathew: drmelwinmathew@gmail.com

Accepted 8 December 2021

\section{DESCRIPTION}

A 54-year-old woman patient reported to the dental clinic with a chief complaint of red gums along with burning sensation, which aggravated on the consumption of spicy or hot food. Medical history revealed that the patient was hypertensive and under medication for the same for 5 years; moreover, the patient was also under treatment by a dermatologist for a skin lesion on both her legs for the past 6 months. On taking a detailed history it was understood from the medical report submitted by the patient that she was being treated for lichen planus and was advised with systemic prednisolone $(30 \mathrm{mg} /$ day $)$. On extraoral examination, flat-topped raised lesions were observed on both of her legs (figure 1). Intraoral examination showed, fiery red gingiva with conspicuous erythema extending from upper right first molar to upper left first molar and lower right first premolar to lower left first premolar (figure 2). The whole thickness of the gingiva (marginal gingiva, interdental papillae and attached gingiva) up to the mucogingival junction was erythematous and tender on palpation with no evident discharge from the gingival sulcus. On examining remaining of the oral mucosa, no significant findings were noticed on the soft tissues; however, generalised accumulation of calculus, plaque and stains was seen. Considering the medical history with intraoral findings of desquamative gingivitis, diagnosis of plaque-induced gingivitis was ruled out and it was finalised as an autoimmune disorder (lichen planus) induced gingival disease.

Desquamative gingivitis is a clinical finding caused due to mucocutaneous conditions particularly like lichen planus, pemphigoid and pemphigus; however, various other aetiologies like allergic reactions to toothpastes/ mouth rinses (plasma cell gingivitis), Crohn's disease, psoriasis, linear IgA disease and chronic
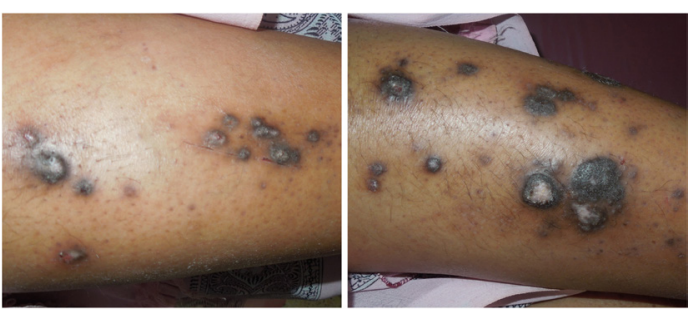

Figure 1 Multiple lichen planus lesions on both the legs of the patient.

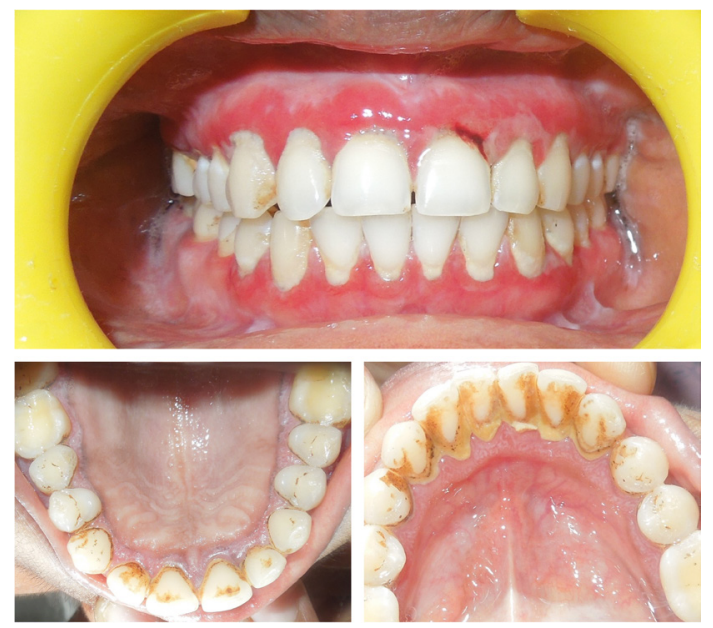

Figure 2 Intraoral view of the oral cavity revealing the presence of desquamative gingivitis with plaque and calculus deposits in the buccal, palatal and lingual areas.

ulcerative stomatitis can also lead to this condition. Clinically, desquamative gingivitis appears as fiery red, glazed, atrophic or eroded looking gingiva with loss of stippling and desquamate easily with minimal trauma. Incidence of desquamative gingivitis is frequently seen in middleaged or elderly women. Due to the multiple potential aetiologies, histological assessment should be done to map the systemic therapy, as it is a rare finding it does not have a systemic guideline for treatment, leading to a disparity in management. An incorrect or delayed identification of desquamative gingivitis can be very crucial as it may lead to inappropriate treatment of serious dermatological disorders. ${ }^{1-3}$

Based on the findings a full mouth scaling was done, oral hygiene instructions were given and the patient was educated regarding the importance of oral hygiene to control the lesion. Since the patient was already undergoing treatment for the lichen planus and treated with systemic

\section{Patient's perspective}

I am surprised to know there is a link between the burning sensation in my gums with the skin lesions on my legs. Now I am extremely aware of how important my oral hygiene is, to reduce this condition, which I have been neglecting for many years and will ensure to do the needful to maintain it well. 


\section{Learning points}

Desquamative gingivitis is a clinical presenting feature most noticed in oral lichen planus. In $10 \%$ of the cases, gingiva can be the only site where the lesion is seen. There have been reports of concomitant involvement of the genital mucosa and the gingiva, especially in women, hence thorough history taking has high significance in diagnosing and treating this mucocutaneous disorder.

- Oral hygiene must be improved, and regular scaling should be emphasised. If other mucosal sites or the skin is involved, then more potent medication such as systemic corticosteroids can be given by referring the patient to the dermatologist.

- If at all there was no systemic involvement, desquamative gingivitis should be treated by following oral hygiene measures and topical therapies. Topical therapy alone is sometimes insufficient to control disease activity. When patients continue to have erosions and pain despite compliance with topical therapy, treatment with systemic therapy is indicated. In the reported case, we considered dermatology referral since the patient was already treated with systemic steroids.

steroid, no further topical steroids were prescribed, rather a topical analgesic was prescribed to reduce the burning sensation. The patient was advised to consult the dermatologist for detailed evaluation of the condition and change in the existing treatment to control the mucocutaneous lesion, which would also reduce the concurrently occurring desquamative gingivitis.

Contributors MM conception and design, acquisition of data or analysis and interpretation of data. Drafting the article or revising it critically for important intellectual content. Final approval of the version published. Agreement to be accountable for the article and to ensure that all questions regarding the accuracy or integrity of the article are investigated and resolved. VSN drafting the article or revising it critically for important intellectual content. SRK final approval of the version published. SS final approval of the version published.

Funding The authors have not declared a specific grant for this research from any funding agency in the public, commercial or not-for-profit sectors.

Competing interests None declared.

Patient consent for publication Consent obtained directly from patient(s).

Provenance and peer review Not commissioned; externally peer reviewed.

Case reports provide a valuable learning resource for the scientific community and can indicate areas of interest for future research. They should not be used in isolation to guide treatment choices or public health policy.

\section{ORCID iD}

Melwin Mathew http://orcid.org/0000-0002-2272-5817

\section{REFERENCES}

1 Robinson NA, Wray D. Desquamative gingivitis: a sign of mucocutaneous disorders-a review. Aust Dent J 2003:48:206-11.

2 Maderal AD, Lee Salisbury P, Jorizzo JL. Desquamative gingivitis: diagnosis and treatment. J Am Acad Dermatol 2018;78:851-61.

3 Pelisse M. The vulvo-vaginal-gingival syndrome. A new form of erosive lichen planus. Int J Dermatol 1989;28:381-4.

Copyright 2021 BMJ Publishing Group. All rights reserved. For permission to reuse any of this content visit

https://www.bmj.com/company/products-services/rights-and-licensing/permissions/

BMJ Case Report Fellows may re-use this article for personal use and teaching without any further permission.

Become a Fellow of BMJ Case Reports today and you can:

- Submit as many cases as you like

Enjoy fast sympathetic peer review and rapid publication of accepted articles

- Access all the published articles

- Re-use any of the published material for personal use and teaching without further permission

Customer Service

If you have any further queries about your subscription, please contact our customer services team on +44 (0) 2071111105 or via email at support@bmj.com.

Visit casereports.bmj.com for more articles like this and to become a Fellow 